\title{
Tendency Message Implementation of Competitive Identity Nation Branding: Wonderful Indonesia
}

\author{
$1^{\mathrm{st} *}$ Novin Farid Styo Wibowo \\ Department of Communication Science \\ Universitas Muhammadiyah Malang \\ Malang, Indonesia \\ novinwibowo@gmail.com
}

\author{
$2^{\text {nd }}$ Yanaita Febrita \\ Department of Communication Science \\ Universitas Muhammadiyah Malang \\ Malang, Indonesia \\ yanaitafebbi@gmail.com
}

\begin{abstract}
Since 2010, Indonesia has announced a nation brand: Wonderful Indonesia which was declared by the Ministry of Tourism as a tourism branding nation in Indonesia. This research takes the Ministry of Tourism and Creative Economy on Instagram @parekraf which has published information to the public as a form of publication of nation branding: Wonderful Indonesia. In the process, this research uses quantitative research methods of content analysis. This research was conducted in September-November 2019 which showed a valid agreement among coders and analysis results where the largest percentage was in the caption and image analysis unit namely the element of tourism promotion (tourism promotion) where the caption was $61.4 \%$ and the figure was $57 \%$. The element that has the lowest percentage is exporting brands at $0 \%$ in each unit of analysis. The other elements are society by $3.5 \%$ in the caption and $8.7 \%$ in the image, culture $0 \%$ in the caption and $7 \%$ in the image, investment $29 \%$ in the caption and $22 \%$ in the image, and policy on a caption of $3.5 \%$ in each unit of analysis. Research suggests that the percentage of culture (exporting culture) and exporting brands should be stronger because it is a important element in representing nation branding.
\end{abstract}

Keywords- Nation Branding, Hexagon Elements of Competitive Identity, Wonderful Indonesia

\section{INTRODUCTION}

Indonesia has implemented nation branding since 2011 which is carried by the Indonesian Ministry of Tourism, which is currently the Ministry of Tourism and Creative Economy with a nation brand: Pesona Indonesia or Wonderful Indonesia. Nation Branding is widely applied in all digital platforms. One of the social media that becomes branding media is Instagram. Based on a journal entitled [1], social media data used by tourists when traveling is Facebook, Instagram, and Twitter. Instagram becomes one of the platforms that users are increasing every year. Quoted from the business instagram page, which was updated in January 2019 , said that the data on active users of Instagram is 62 million users while the active users of Instagram every day are 30 million users. Content published on Instagram must also be considered in terms of portions and proposals so that the nation branding that is formed can be fully accepted [2].

Since 1980, the phenomenon of nation branding has attracted the attention of governments and academics [3]. Nation branding is one of the tools used by the private sector and the government to create a competitive national image in the global market combining marketing and technical branding as a tool [4].
A successful nation brand is assumed to be able to compete for international capital: tourists, investment, import-export trade, skilled labor and highly educated international students; and to foster the competitiveness of national companies. It also helps to "convey an image of legitimacy and authority in diplomatic arenas [5].

In theory, in forming opinions and good impressions in the public Simon Anholt carries the hexagon competitive identity theory which is about the element of nation branding that should be applied. This theory explains that there are 6 elements, namely based on people who are in a country, tourism (promoting tourism), culture, goods that are exported (exporting), investment, and policy [2]. Therefore, knowing the portion and proposition of the application of these 6 elements is important so that the nation's identity is known by the public. The purpose of the study is to measure the portion and proposition of the implementation of messages and evaluation materials and as a follow up to conduct more indepth research with different methods for the Competitive Identity Element in Nation Branding: Wonderful Indonesia on the Official Instagram Account of the Ministry of Tourism and Creative Economy (@parekraf).

\section{RESEARCH METHOD}

This research uses a positivistic approach that produces quantitative research methods. This research was conducted by collecting data in the form of numbers and text which are then processed and analyzed to obtain additional scientific information [6].

In carrying out content analysis research, there are several steps to maximize and obtain the correct procedure with the following stages:

- Sources that have been selected and become the scope of research are carried out sampling using the total sampling method

- Look for or refer a theory into a categorization.

- Conduct a coding process with coders that are in accordance with predetermined criteria.

- Analyze and interpret the analysis of the previous process.

\section{A. The scope of research}

From the scope of the study with a total upload of 221 posts in the period September to November 2019, then the researchers made a population limit. Here are the population 
restrictions for the September to November 2019 period on the @ parekraf Instagram account:

- Content related to branding: Wonderfull Indonesia

- Uploads represent people; tourism, culture, exporting brands, investment and foreign and local policies that are in accordance with the Hexagon Competitive Identity

- Upload is not a repetition of similar content.

- Uploads that have a number of likes above 500

- The upload has an explanation in the Instagram description box

- Upload according to facts or objectives

By using the population limitation for the period September 2019-November 2019 on the Instagram account @ parekraf above there are 57 uploads. In the process, the research room has changed its name from the Ministry of Tourism @kemenpar to the Ministry of Tourism and Creative Economy @parekraf. The upload to be examined is attached to the page.

\section{B. Unit of Analysis and Unit of Measurement}

In this study, the unit of analysis is photographs and captions containing the message of nation branding in the September to November 2019 period on the @ parekraf instagram page. The unit of measure refers to the period taken by the researcher in carrying out the research process. In this dal, the Instagram Ministry of Tourism and Creative Economy with the user name is @ parekraf from September to November 2019

\section{Data collection technique}

Researchers used documentation techniques by documenting content and photos in the upload of the Indonesian Ministry of Tourism and Creative Economy (@parekraf) on Instagram in accordance with population limits that have been determined by the screen capture feature. After collecting data, the data obtained is transferred to a worksheet (coding sheet) by the researcher adjusted to the Hexagon Competitive Identity category.

\section{Validity test}

In this study, researchers chose someone who has done research on content analysis before and understands what nation-branding is, especially Wonderful Indonesia. Researchers choose experts from people who understand the concept of nation branding: Wonderful Indonesia and understand the concept of hexagon competitive identity and can analyze objectively in the upload of the Indonesian Ministry of Tourism and Creative Economy (@ parekraf)

\section{E. Reliability Test}

In this study, the formula from Holsty is used to formulate validity in this study with the following formula:

$$
\mathrm{XP}=2 \mathrm{M} / \mathrm{N} 1+\mathrm{N} 2
$$

\section{Information}

M: The same amount of coding (agreed by each code)
N1: Number of coding made by coder 1

\section{$\mathrm{N} 2$ : Number of coding made by coder 2}

After passing the reliability test by applying the formula from Hostly, the agreement of the code is tested again to improve the weaknesses of the Hostly formula which results in the percentage of occurrence of categorization and the opportunity of this research being tested by the formula or formula from Scoot pi, where in this case the expected thing is calculate how the formula between the coders and researchers:

$P i=\%$ agreement that was observed - \%Agreement that expected/1-\%Agreement that expecte

\section{Information}

Pi: reliability between coders

\section{RESULT AND DISCUSSION}

The Ministry of Tourism released the nation's branding titled Wonderful Indonesia as a branding of tourism in Indonesia which aims to better introduce and represent Indonesian tourism and attract foreign tourists to visit Indonesia. The branding nation that was built was delivered from programs that have been prepared by the Ministry of Tourism, which is currently the Ministry of Tourism and Creative Economy (@parekraf). As has been explained textually in the introductory chapter, it is explained that Simon Anholt as a nation branding expert has the Hexagon Competitive Identity theory which outlines the elements that must be possessed by nation branding actors. There are 6 elements that were finally made into research categorizations by researchers namely People, Tourism Promotion, Culture, Exporting Brands, Investment, Policy. Based on the analysis and calculations that the researchers have explained, the results show that there are 6 categories with 57 articles that have been studied. But not all categories of nation branding elements: Wonderful Indonesia appears in the upload of the Ministry of Tourism and Creative Economy (@parekraf). There are only 4 categories that emerge from the caption analysis unit, namely the people, the tourism promotion, investment, and policy categories. And the categories that do not appear are culture and exporting brands (products that are exported). While the image analysis unit there are 5 categories that appear, namely people, tourism promotion, culture, investment, and policy. And the category that does not appear is exporting brands (products that are exported).

The results of the analysis showed the most widely loaded themes on Instagram Ministry of Tourism and Creative Economy (@parekraf) in September to November 2019, namely the caption analysis unit in the category of tourism promotion obtained an average of 0.631 or 36 captions from 57 total data. In the image analysis unit also the category of tourism promotion appears most with an average appearance of 0.578 or as many as 33 images. The tourism promotion category is a category that offers tourism product visits both destinations or events both explicitly and implicitly, the images shown are also in the form of tourist destinations or informative graphic designs related to tourism promotion.

In the second place the results of the analysis of the caption analysis unit the most uploaded category is investment in the Ministry of Tourism and Creative Economy (@parekraf) 
which is an average of 0.314 or as many as 17 uploads. Whereas in the image analysis unit investment categorization is also the category that most appears with an average of 0.228 or as many as 13 posts the second unit of analysis in September to November 2019. Investment is information about managing investment in a country, the investment element focuses in management rather than investment products or types of investments that are loaded.

As for the other categorizations that appear in the Instagram upload of the Ministry of Tourism and Creative Economy in the caption analysis unit there are people categorizations with an average of 0.192 or as many as 2 occurrences, policy categorization (policy) with an average of 0.192 or as many as 2 occurrences. Both of these categorizations have a low occurrence rate in the caption analysis unit. While the categorization that does not appear in the caption analysis unit is the categorization of culture and export brands.

\section{CONCLUSION}

Based on calculations that have been done by researchers through the frequency distribution table of six categories, then obtain the following results:

1) Caption Analysis Unit

- People $=3.5 \%$

- Tourism Promotion $=61.4 \%$

- Culture $=0 \%$

- $\quad$ Exporting Brands $=0 \%$

- Investment $=29 \%$

- Policy $=3.5 \%$

2) Image Analysis Unit

- People $($ Society $)=8.7 \%$
- Tourism Promotion $=57 \%$

- Culture $=7 \%$

- Exporting Brands (Goods exported $)=0 \%$

- Investment (Investment $)=22 \%$

- Policy $=3.5 \%$

In the process of analysis, there are some relations between the caption and the image so that the percentage between the caption and image categorization has differences. As with the culture element in the caption categorization it has a percentage of $0 \%$ while in the figure there is $7 \%$ with quite a different comparison, the researcher concludes that the Ministry of Tourism and Creative Economy displays images that are related to culture but the caption does not explain culture.

\section{REFERENCES}

[1] Zehra Altinay, Tulen Saner, Nesrin M. Bahçelerli dan Fahriye Altinay. January 2016, "The Role Media Social Tools: Accessible Tourism", $\begin{array}{lllll}\text { (accessed } & \text { on } & 20 & \text { April } & \text { 2019), }\end{array}$ [https://www.researchgate.net/publication/]

[2] Jessica Viktorin C.E, Glenowhect, Estner, K.Will, "Nations Branding in Modern History" New York: Berghahn Books, 2018, pp 62-66

[3] Sri Utami, Vanessa Gaffar, "Tourism and Hospitality Essentials (THE) Journal”, Vol.IV No.1.2014 - 698, 2014, [https://www.academia.edu/28682123]

[4] Sharma Hassan, "Tourism Event in Asia: Marketing and Development”, New York: Routledge, 2011, pp 23-24

[5] Melissa Aronczyk, "Branding The Nations: The Global Business of National Identity" New York: Oxford University Press, 2013, pp.1821

[6] Eriyanto, "Analisis Isi: Pengantar Metodologi untuk Penelitian Ilmu Komunikasi dan Ilmu-ilmu Sosial Lainnya”, Jakarta: Kencana, 2011, pp.56-59 